\title{
The Challenges in Developing E-Content
}

\author{
doi:10.3991/ijet.v5s3.1505 \\ Dr Juhary, J. \\ Universiti Pertahanan Nasional Malaysia, Kuala Lumpur, Malaysia
}

\begin{abstract}
Malaysia is considered an active key player in information communication technologies (ICTs) especially in education. In fact, in the National Higher Education Strategic Plan, one of the Critical Agenda Projects (CAPs) of the Minister of Higher Education is e-learning. It goes without saying that all higher learning providers in Malaysia must be prepared to provide state-of-the-art facilities for the students. One critical aspect of e-learning is the quality and quantity of the content, or what will be referred by many scholars as e-content. This paper attempts to identify the challenges of content development for e-learning practice at the National Defence University of Malaysia (NDUM). It is crucial to investigate this issue since the university just purchased its Learning Management System (LMS). It is expected that resistance will be present as the academics at the defence university is a mixture of junior and senior lecturers, as well as civilian and military lecturers; and some of these academics have been teaching without the assistance of e-learning. In so doing, the methodology of this paper will mainly be content analysis of various reports, governmental documents, as well as semi-structured interviews with lecturers at the NDUM. As this paper acts as a preliminary investigation into the issue of e-content at the university, only seven lecturers were interviewed. Initial findings suggest that there are basically five challenges of developing econtent at the NDUM. These include the lack of ICT and elearning policy that can provide guidelines to academics; the uncertainty of ownership for e-learning initiatives; the lack of understanding of the roles of e-learning; the lack of awareness on e-learning; and the difficulties to develop military based content due to confidentiality issues. Two possible solutions for these challenges are also examined which take into consideration the urgent need to set up an eLearning Unit and to provide series of workshops and seminars of teaching with technology, or relevant courses. It is found that in the effort to give students the exposure to and experience of e-learning, the first step in the implementation phase, which is to develop e-content, has alerted the university of the various fundamental challenges that need to be addressed accordingly.
\end{abstract}

Index Terms - content development; e-content; e-learning

\section{INTRODUCTION}

Academic excellence is always difficult to achieve if the perceptions of stakeholders including students, lecturers and industries vary. This seems especially true for a unique learning environment such as the National Defence University of Malaysia (NDUM), which gives equal emphasis between academic excellence and military performance. It is inevitable for students at the NDUM to perceive that their life is tough because they have to undergo both academic and military training concurrently. Nonetheless, as the youngest public university in Malaysia, the management is constantly finding ways to guarantee that students can achieve their optimum potential in both aspects, and thus changing the perceptions of all involved.

One of the strategies used by the university is improving the information communication technologies (ICTs) which cover educational and administrative domains. ICTs refer to networked communication systems and distributed learning technologies including e-learning. This paper is not to discuss the relation between academic achievement and the use of ICT in education. There is much literature and a lot of debates on whether ICT assists in students' academic performance (for example see [1]; [2]). Rather, this paper attempts to identify the challenges of content development for e-learning practice at the NDUM.

\section{A. The National Defence University of Malaysia}

The NDUM is a unique university; a one of a kind institution in the world. This is because it is the first university that awards undergraduate degrees and confers military rank of Captain or equivalent to its graduates. The university houses selected trainees from the three different services (army, navy and air force) under one roof, and graduates of this university will serve the Malaysian Armed Forces (MAF). The NDUM started with the establishment of the Military Academy of Malaysia in 1995. Programmes at the establishment were based on cooperation between the Ministry of Defence, Malaysia which provided military training programmes and Universiti Teknologi Malaysia (UTM) (a public university) which provided the academic training component. UTM was a 'natural choice' as the academic partner because of its reputation in engineering degrees. This reflected the pressure on the armed forces to ensure that the training of new military manpower included a large number of welltrained engineers. The first cohort of undergraduate cadet officers totalling 172 started their military and tertiary education at the academy in June 1995 [3].

Because of the importance of properly educating future military officers, the government felt that the academy should be upgraded. This will ensure that the focus of the establishment is sharpened, and the teaching and learning processes become more systematic. As such in November 2006, the academy became a university. This upgrade slightly shifts the focus of the university, which is now to pioneer the creation of academically trained military leadership capable of placing the nation's security interests into a broader regional and global framework. Suitable learning programmes, coupled with suitable learning deliveries, are now needed to ensure that the 'future guardians' of Malaysia received the best education so that they could become talented and loyal defenders of the nation.

\section{B. The Methodology}

Data for this paper derived from content analysis of various documents as well as semi structured interviews 
of academic staff of the university. The analysis of semi structured interviews is done manually based on themes explored during the interviews. Due to the right for privacy of the interviewees, their names will not be used in this paper. Rather, codes will be assigned to all seven interviewees: R1 to R7. Their backgrounds range from engineering to management fields.

Before analysing further, it is important to understand how the paper is developed. This paper is divided into four main sections. Apart from the introduction, the second section discusses e-learning in education and training. This section gives a crucial overview of the importance of e-learning in today's learning environment especially in Malaysia. The third section is the analysis and discussion section; this is the heart of the paper where the analysis of data collected will reflect the significance of issues highlighted. The last section concludes the analysis of this paper.

\section{E-LEARNING}

In this section, the discussion will be directed to two main issues, namely e-learning in Malaysia as a whole and the framework of e-learning itself.

\section{A. E-Learning in Malaysia}

Launched in 2004, the National Higher Education Strategic Plan aims at increasing the nation's competitiveness, productivity and innovativeness [4]. Under this comprehensive plan, there are seven thrusts, and each has its own master plan to be implemented. As this is a national strategic plan, all these thrusts are monitored closely by the Minister of Higher Education; they become the Minister's Critical Agenda Projects (CAPs). One of these thrusts, Enculturation of Lifelong Learning, emphasises the importance of ICTs in delivering quality education. This is where e-learning becomes the tool to democratise education. e-Learning as a CAP has one published Strategic Objective (SO), which is all higher learning institutions in Malaysia must have a platform to run e-learning initiatives. Scholars in education in Malaysia have found that this one SO is insufficient, and at present, roundtable discussions are held to formulate a few other SOs for elearning.

Malaysia is considered a young and yet an active player in e-learning revolution. In a survey conducted in 2002, the growth rate of e-learning in Malaysia is 16 percent. This was ahead of Taiwan, Hong Kong and New Zealand which had a growth rate of 13 percent, 13 percent and 9 percent respectively [5]. Officially, e-learning in Malaysia began in 1998 when the first virtual university, Universiti Tun Abdul Razak (UNITAR) started its academic programmes. Ever since, many higher learning institutions in Malaysia commence their e-learning projects through open source platforms or purchases of Learning Management Systems (LMSs) such as Blackboard or WebCT. These efforts are further supported by the initiatives funded by Malaysian government itself. For example, as discussed earlier, the National Higher Education Strategic Plan outlines several critical agendas, and one of those is the dependency on new technologies for cost effective delivery [6]. Another effort to ensure e-learning is supported at higher learning institutions is the establishment of the Malaysian e-Learning for Public Universities Association (MEIPTA). This association is represented by co- ordinators of e-learning units/departments from all 20 public universities who meet four times per year to discuss and share issues on policies, implementation, training, systems and many more. The author, attending the meeting on the capacity of her research interest, and not to represent an e-Learning Unit at the NDUM, learns a lot from the meetings attended. Given that her university is the youngest public university, little is to be shared but many to ponder and reflect upon the experiences of more established universities. It could be concluded that e-learning in Malaysia is adopting a blended approach where face-toface sessions are very much critical to students' learning processes; nevertheless, some universities in Malaysia have reduced the number of face-to-face contact hours due to extensive e-learning practices.

Why is content development significant in e-learning? Or rather, why is e-content so crucial? According to Chai Lee Goi and Poh Yen Ng [7], programme content is the most important factor that determines the success of elearning in Malaysia. Supporting this argument in one of his speeches, the President of Open University Malaysia (OUM), Professor Dr Anuwar Ali outlines a few key issues and challenges of implementing e-learning in Malaysia. At the end of the speech, he suggests one critical agenda, which is the set up of National e-Content Development Centre [8]. He further cautions practitioners of elearning that developing content is not the only issue; rather developing quality content is a more demanding task. It is argued by scholars that content development is amongst the most critical stage because it is one of the earlier stages in e-learning implementation. As illustrated by Muhammad Rais Abdul Karim and Yusup Hashim [9], content experts are second after the Head of Departments in the flow chart of the Design and Development Committee, Universiti Pendidikan Sultan Idris, Malaysia. What could be learnt from the above citations as well as the other literature are twofold: content development is vital in providing students the best e-learning experiences and quality content is a success factor in e-learning.

The next question to ask is how could the armed forces benefit from e-learning practices? Because of the experiences of UNITAR as the first university to introduce elearning, in August 2002, the MAF started its e-learning programme with the first virtual university. This programme caters to in service personnel who are either sent by the MAF or who themselves applied for the programme. Upon completion of their studies, they will be awarded undergraduate degrees by UNITAR. It is critical to mention that the practice of e-learning at UNITAR for part time personnel is a blended one; they still have to attend face-to-face sessions at least for a few hours per semester depending on the faculties' requirement. By embarking on this programme, the MAF has acknowledged that e-learning can help its personnel to advance their career by improving their academic qualifications. The rest of the MAF's efforts for e-learning go to its educational institutions namely the Royal Military College (RMC) and single service colleges. The RMC, for instance, uses elearning to support its face-to-face sessions and the single service colleges use e-learning to help military trainees hone their mastery of skills. It is interesting to note that the NDUM, when it was previously known as a military academy, was not given the task to adapt e-learning. There is no opportunity to explore this issue here; rather the decision now is that the defence university would like to 
utilise e-learning to enhance the teaching and learning process.

\section{B. The Underlying Framework and Issues for e-Learning}

The enormous investment that military organisations, especially the U.S. military, have made in new educational technologies has allowed military trainees to pursue their own self-motivated studies in a manner that was never possible before (see [10]). The earlier, traditional approaches to learning have been described by many as inspired by behaviourist approaches. The behaviourist school of thought was first articulated by Thorndike, Pavlov, Watson and Skinner. What they all shared was the belief that similar to animals, human beings were creatures whose behaviour could be conditioned by repetitive learning exercises in which certain types of 'desirable' acts were rewarded and other, 'undesirable' acts, were not rewarded or 'reinforced'. Taking these ideas into human learning, behaviourist educators insisted that students learnt better when they were "drill[ed] and [forced to] practice” [11]. The act of 'learning' was itself defined as something that took place when there was a change in the behaviour of the subject - a change in a manner compliant with the requirements of the instructor [12]. Implicit in these views was the notion that the 'teacher' had superior knowledge and was in control of a finite amount of desirable knowledge that had to be imparted to the subjects.

It would be easy to assume that learning environments within a military context have always been dependent on drill-and-practice techniques [13]. These techniques, in turn, reflect the view that military discipline is best promoted by ensuring that military trainees acquire skills that enable rapid responses to command. Such assumptions appear to conform to behaviourist expectations. In fact, the first courseware, called CAI or Computer Assisted Instruction, which was designed and introduced in the 1970s [14] applied drill-and-practice [15] techniques to condition students' learning. Nevertheless, as learning theories evolve over time, so does the framework use for courseware design and development. Although the basis of behaviourism is still very much intact at the lower level of courseware development, for higher intellectually challenged activities, constructivism is becoming a critical component.

"Constructivism is not a particular approach to teaching, it is a view of how learning occurs that has important implications for teaching and in particular for the studentteacher and student-student discourse that occurs in the classroom” [16]; [17]. Mitchell's concise definition provides an important way of moving through the vast quantity of research reports that have been written on constructivism - much of it is misleading because it oversimplifies the implications of the teaching philosophies that emerge from it. Based on 26 years of research on the teaching process in classrooms, Mitchell establishes the key dichotomies between transmissive and interpretative teachers. The latter is 'learner-sensitive' [18]. To sum up, constructivists insist that knowledge is never finite but forever evolving into expanded, deeper and more significant meanings. It is the role of the teacher to guide that process of learning.

How does this knowledge of behaviourist and constructivist principles help content developers to design and develop e-content? For the NDUM, two aspects are significant. The first one is the presence or absence of teach- ing and learning philosophy at the university reflects the incomplete process of developing appropriate contents for e-learning. Should the university adopt a blended teaching practice, that is the combination of face-to-face and elearning, the content development for e-learning must ensure that students can interact with the materials. As beginners, academics at the university must be warned of the difference between 'cutting and pasting' content from printed texts onto e-learning pages on computer screens. Thus selection of words, phrases and sentences are vital since e-learning offers a different learning medium altogether. The second is the process of developing content must take into consideration students' level of studies and level of proficiency. For fundamental courses, mastery of knowledge is crucial. Therefore, the way the content is developed should adapt the behaviourist principles. As the courses progress, so do the students' level of understanding and knowledge. At this point the constructivist principles can be used to guide content development for elearning. Ideally, the students will be able to understand their own learning process, that is, from being receivers of information to becoming independent thinkers.

This section has argued that e-learning is crucial in today's learning environment. It also argues that the use of appropriate learning framework to develop e-learning and its content is decisive in making certain that the institutions can benefit. The question now is how far can the NDUM absorb the processes involved in developing contents for e-learning and transform all challenges into effective learning solutions. This will be explored next.

\section{ANALYIS AND DisCUSSION}

It is imperative to provide a background synopsis for the e-learning project at the NDUM. Planning began in the middle of 2008 to have a full fledged e-learning system. Previously, only one academic programme at the NDUM has used e-learning extensively [19]. Learning from this internal experience, and because of the pressure by other higher learning institutions in Malaysia, the NDUM finds that e-learning could provide the missing link in complementing students' learning process. Despite the challenges that will be explained later, the university has started to engage on the process of purchasing a LMS from a private company to expedite the e-learning project. In this manner, the NDUM has fulfilled the SO of e-Leaning CAP (see earlier section). Concurrently, an ad-hoc committee has been set up to look into many facets of e-learning including quality contents. Based on the data gathered from seven interview respondents, it is found that five important challenges for e-content development at the university have emerged.

The first challenge relates to the non-existence of neither ICT nor e-learning policy at the NDUM. As an institution at its infancy stage, this seems acceptable; however it poses questions on issues such as the guidelines and validity of developing e-learning contents. Guidelines refer to issues ranging from technical aspects to copyright and security of contents. Validity suggests whether the contents for e-learning are suitable in terms of level of difficulty and the most appropriate contents to be developed. All respondents were not aware of any ICT policy, let alone e-learning policy at the NDUM. R4 suggested that before further attempt is made on engaging academic staff to develop contents for e-learning, the policies involving the practice of e-learning and ICT must be made 
known. Regardless of the approach taken by the management, these policies are the framework for a successful elearning implementation. Although the absence of the policies may not affect the initial running of an e-learning operation, it is a reasonable step if other higher learning institutions' e-learning policies are analysed. Besides learning from other institutions that have used e-learning for a longer period of time, the NDUM can identify the local best practice for e-learning, and thus use it as a point of reference.

The second challenge is on the ownership of e-learning initiatives at the NDUM. Prensky [20] suggested that for any projects involving ICT, there must be a champion in order to guarantee a successful implementation of the new projects. At the university, understanding ownership of elearning and taking the appropriate measures for elearning are two different sub-challenges altogether. Because there is no clear policy as analysed in the first challenge, it is difficult to issue an instruction to develop contents for e-learning. The content for the only e-learning practice at the NDUM is not tailor-made; it was purchased from a private company abroad. The problem with this practice is that the content does not have local flavour that the students can relate to. R1 and R2, from the only academic programme that has e-learning at the university, commented that students complain about two things; firstly, the data about shores and weather in the courseware do not really represent the reality in Malaysia, and secondly, the depiction of cultures also differ greatly from Malaysia. While the contrast may not influence students' understanding of the lessons, R1 said that it is high time that the university develops its own contents for elearning. These custom-made contents will need to pay close attention to students' understanding of local issues including the socio-economic background. Gradually, the contents can relate to Malaysia's involvement in international affairs.

The third challenge is on convincing the faculty to understand the roles of e-learning for tertiary education. Without the convictions, content development is a futile attempt. R5 suggested that making people understand the new way of learning is more difficult than developing the content. This argument speaks for itself; nonetheless it is critical that everybody is involved in developing the content. The NDUM offers more than 200 courses and all these must have their own content developers. Besides, the involvement of all academics allows them to claim ownership of the e-learning project since they are directly involved in it. R5 further commented that it will be a challenging first three year to develop the content; after that it is the matter of maintaining and upgrading the content. A different point is brought up by R6 when she said that the roles of e-learning have been quite vague in students' process of learning. She related her experience of using elearning for a short course where she found that after a while she lost interest in it. While R6 had a point to make, the author summed up that part of the problems lies with the content which is not stimulating and challenging. This means that at some point or the other, appropriate content will help students to understand their lessons better and thus retain their attention.

The fourth challenge is on the awareness level of academic staff about the importance of providing students with alternative or supporting tool for learning, which happens to be very low. Although this is an old time issue, it is remarkable that some academics do not 'appear' to understand the significance of training students with new technologies. Four respondents were very sceptical about e-learning. While these academics may not represent the whole university, their concerns must be addressed carefully. R3 said that while he was not against the use of ICT technologies, he was trained in a conventional environment and yet managed to master the required knowledge. He further stressed that many of the great leaders today were not also trained using e-learning; what is important is the content, not the delivery method. The author would like to argue that this may be caused by the lack of understanding about the learning theories and the concept of how students learn. As much as the arguments of R3 are valid, the other aspect of teaching and learning is not discussed, which is the students themselves. Being exposed to ICT at a young age at home and schools, students would expect that their tertiary education is conducted in such a way that allows them to relate to their previous experience and knowledge. R1 argued that students may not want to step out of their comfort zone, that is, they are afraid to embrace new ways of learning. Given this, it is the task of the educators to encourage students to embark and explore through new learning media including elearning.

The last challenge is on content development for military related courses, which is bound by confidentiality and security issues, and these have hindered the participation of 'real' people who understand the running of military institution, culture and life to contribute to content development for military related courses. Although the university can always refer to the existing policies prepared by the National Security Council, about security and confidentiality of military learning and teaching materials, miscommunication and misleading of information will occur at one point or the other. R7 concluded that her experience dealing with documents labelled as 'confidential' or 'limited' is challenging. Not only do the documents need to go through various committees before being made public, but also the nature of bureaucracy system makes some experts in the areas reluctant to contribute in developing appropriate content for e-learning. Further, the security of the servers for e-learning is also questioned by two respondents, R4 and R5. One talked about the firewall that must be stable. At present, the firewall installed has been experiencing a lot of failure. Although this may be temporary, it actually reflects on the capability of the university to provide for and protect its interest. The other talked about the security of the content after being uploaded to the server. Since the firewall itself can be a problem, there is no guarantee that the content will be saved from any malicious attacks and threats.

To sum up this section, content development for elearning appears to have five challenges. All these challenges require different treatments each; notwithstanding this, one fundamental treatment is the change of mindsets and attitudes of staff and students alike at the university.

\section{CONCLUSION}

There are various ways to overcome the challenges discussed in the previous section. The short term and critical actions that can be taken up are twofold. The first action is to set up an e-Learning Unit at the NDUM. The existing ad-hoc committee must be converted to a unit on its own so that the administration and implementation of e- 
learning will be efficient. Because this unit is an independent unit in the university, it will have its own staff and budgets. This ensures that whatever needs to be done, there will be no issues of lack of manpower or budgets. This unit will also be responsible to draw up e-learning policies for the NDUM. The second action is by planning a series of workshops and seminars about content developments for e-learning. To date, only one workshop has been conducted and the participation did not cover all academic staff due to several restrictions. The workshops must be arranged in such a way that allows the participants to understand important issues including the concept of teaching with technology, learning theories, testing and evaluation, the use of ICT in education, and material selections for learning with computers.

The NDUM has a long way to go in terms of providing the best e-learning solutions to its students. Despite the restrictions, the management realises that students are learning differently today than 20 years ago. It is the responsibility of the management to make certain that students are given the options in their learning process. Some of the resistance can be put aside when educators realise that e-learning will never replace conventional ways of teaching and learning, face-to-face. The NDUM takes elearning as only a supplementary learning approach. What e-learning offers is an innovative way of assisting students to achieve their potential. This innovative way will only be possible if the content is appropriate and relevant to the students. The university believes that for whatever reasons that e-learning is useful for, the content of e-learning is the most critical facet of enhancing students' learning process, hence ensuring successful implementation of e-learning.

This paper has demonstrated that the challenges for elearning and content development of it in particular, are mainly because of the lack of understanding of e-learning as a complementary tool in classrooms. The perception that e-learning will take over the learning process from real life teacher is threatening many educators. Coupled with this lack of understanding, the level of awareness of educators in terms of the potential of e-learning is also a contributing factor. Five out of seven respondents of this paper still have a vague impression of e-learning. This is not from lack of exposure to e-learning; rather the author concluded that this is due to the 'could-not-care-less' attitude that some academics have towards new ways of teaching and learning.

In conclusion, the coming years will definitely see a lot of works that need to be accomplished in order to have successful e-learning. It is not a one-day process where everybody will understand and agree; there will be debates and arguments about the best way of educating students at the NDUM. Given the expectations of all stakeholders for the graduates are high, amongst others their ability to compete globally, it is only reasonable that they should be educated and trained with the best combination of teaching and learning approaches and tools, one perhaps being e-learning technologies. These technologies, nevertheless, will not be useful if the content lacks quality and suitability.

\section{REFERENCES}

[1] Jong-Ho Shin et al. (2005), "Research on Factors Influencing Academic Achievements in an e-Learning Environment,” KERISKR 2005-35.
[2] Khine, S. M. (2003), "Creating a Technology-Rich Constructivist Learning Environment in a classroom management module," in Khine, S. M. and Fisher, D. (Eds.), Technology-Rich Learning Environments, World Scientific, New Jersey, pp. 21-40.

[3] Expand Your Mind, Go Beyond The Limits. (2005), The Office of the Commandant. The Military Academy of Malaysia, Kuala Lumpur.

[4] National Higher Education Strategic Plan Beyond 2020. (2004). Kuala Lumpur: Ministry of Higher Education Malaysia.

[5] AEN Survey Research. (2002), "Survey Research on e-Learning in Asian countries - fiscal year. http://www.asia-learning.net/con tent/realatedInfo/report.html

[6] National Higher Education Action Plan 2007-2010. (2007). Kuala Lumpur: Ministry of Higher Education Malaysia.

[7] Chai Lee Goi and Poh Yen Ng. (2009), "e-Learning in Malaysia: Success Factors in Implementing e-Learning Programme," International Journal of Teaching and Learning in Higher Education, Vol 20, No. 2 , pp. 237-246.

[8] Anuwar Ali, President of Open University Malaysia. A speech accessed at http://asiapacific-odl2.oum.edu.my/C33/F80.pdf

[9] Muhammad Rais Abdul Karim and Yusup Hashim. (2004), “The Experience of e-Learning Implementation at the Universiti Pendidikan Sultan Idris Malaysia," Malaysia Online Journal of Instructional Technology, Vol 1, No. 1, pp. 50-59.

[10] Juhary, J. (2007), The Military Academy of Malaysia compared with West Point: Learning Environments and New Technologies, PhD Dissertation, Monash Asia Institute, Monash University Melbourne Australia.

[11] Skinner, B.F. (1974), About Behaviourism, Jonathan Cape Ltd., London.

[12] Skinner, B.F. (1987), Upon Further Reflection, Prentice-Hall, Inc., New Jersey.

[13] van Ree, A. J. (2002), “Towards a Military Pedagogy,” in Florian, H. (Ed.), Military Pedagogy - An International Survey, Peter Lang, Frankfurt, pp. 29-46.

[14] Saettler, P. (1990), The Evolution of American Educational Technology, Libraries Unlimited, Inc., Englewood, CO.

[15] Kosakowski, J. (1998), "The Benefits of Information Technology,” Eric Digest. EDO-IR-98-04.

[16] Mitchell, I. (11 ${ }^{\text {th }}$ November 2007a), Senior Lecturer, Faculty of Education, Monash University, Clayton Campus, Melbourne, Australia, (Email Correspondence).

[17] Jaworski, B. (1993), "Constructivism and Teaching: The Sociocultural Context," A Paper Presented at a Seminar on the Mathematics Teaching and Learning Enquiry Group, Manchester, January.

[18] Mitchell, I. (2007b), “The Relationship between Teachers Behaviours and Student Talk in Promoting Quality Learning in Science Classroom," MS.

[19] Juhary, J. (2007), The Military Academy of Malaysia compared with West Point: Learning Environments and New Technologies, $\mathrm{PhD}$ Dissertation, Monash Asia Institute, Monash University Melbourne Australia.

[20] Prensky, M. (2001), Digital Game-Based Learning, McGraw Hill, New York.

\section{AUTHORS}

Dr J. Juhary is with the Centre for Liberal and Language Studies, Universiti Pertahanan Nasional Malaysia (National Defence Universiti of Malayia), Sungai Besi Camp, 57000 Kuala Lumpur, Malaysia (email: atiejay@gmail.com).

This work received permission by the National Defence University of Malaysia to conduct interviews of the academic staff.

Manuscript received November $7^{\text {th }}, 2010$. Published as submitted by the authors November $22^{\text {nd }}, 2010$. 